MISS HANNAH ELISE FOGARTY (Orcid ID : 0000-0001-7261-2565)

Received Date : 24-Jun-2016

Revised Date : 25-Oct-2016

Accepted Date : 19-Dec-2016

Article type : Primary Research Articles

\title{
Are fish outside their usual ranges early indicators of climate-driven range shifts?
}

Hannah E. Fogarty ${ }^{1,2}$, Michael T. Burrows ${ }^{3}$, Gretta T. Pecl ${ }^{1}$, Lucy M. Robinson ${ }^{1,4}$, Elvira S.

Poloczanska ${ }^{2,5,+}$

${ }^{1}$ Institute for Marine and Antarctic Studies, Private Bag 49, Hobart, Tasmania 7001, Australia

${ }^{2}$ CSIRO Oceans and Atmosphere, Queensland Bioscience Precinct, St Lucia, Queensland 4067, Australia

${ }^{3}$ Scottish Association for Marine Science, Oban, Argyll PA37 1QA, UK

${ }^{4}$ Commission for the Conservation of Antarctic Marine Living Resources, Hobart, Tasmania

7000, Australia

${ }^{5}$ The Global Change Institute, The University of Queensland, St Lucia, Queensland 4067,

Australia

+Current address: Alfred Wegener Institute for Polar and Marine Research, 27515

Bremerhaven, Germany

* Corresponding author.

Elvira Poloczanska

Phone: +61 (7) 38335956

Email: elvira.poloczanksa@awi.de

This article has been accepted for publication and undergone full peer review but has not been through the copyediting, typesetting, pagination and proofreading process, which may lead to differences between this version and the Version of Record. Please cite this article as doi: $10.1111 /$ gcb. 13635

This article is protected by copyright. All rights reserved. 
Keywords: Climate change, range-shift, range-edge, climate velocity, detection and attribution.

\section{ABSTRACT}

Shifts in species ranges are a global phenomenon, well known to occur in response to a changing climate. New species arriving in an area may become pest species, modify ecosystem structure, or represent challenges or opportunities for fisheries and recreation. Early detection of range shifts and prompt implementation of any appropriate management strategies is therefore crucial. This study investigates whether "first sightings" of marine species outside their normal ranges could provide an early warning of impending climatedriven range shifts. We examine the relationships between first sightings and marine regions defined by patterns of local climate velocities (calculated on a 50-year time scale), while also considering the distribution of observational effort (i.e. number of sampling days recorded with biological observations in global databases). The marine trajectory regions include climate 'source' regions (areas lacking connections to warmer areas), 'corridor' regions (areas where moving isotherms converge), and 'sink' regions (areas where isotherms locally disappear). Additionally, we investigate the latitudinal band in which first sightings were recorded, and species' thermal affiliations. We found that first sightings are more likely to occur in climate sink and 'divergent' regions (areas where many rapid and diverging climate trajectories pass through) indicating a role of temperature in driving changes in marine species distributions. The majority of our fish first sightings appear to be tropical and subtropical species moving towards high latitudes, as would be expected in climate warming. Our results indicate that first sightings are likely related to longer-term climatic processes, and therefore have potential use to indicate likely climate-driven range shifts. The development of an approach to detect impending range shifts at an early stage will allow resource managers 
and researchers to better manage opportunities resulting from range-shifting species before they potentially colonise.

\section{INTRODUCTION}

Climate change is expected to become the greatest global driver of marine biodiversity change within the next few decades as species respond to changes in temperature, dissolved oxygen, acidity and nutrient availability, among other factors (Hoegh-Guldberg et al., 2014; Pörtner et al., 2014). Temperature is a key driver of existing marine biodiversity patterns (Tittensor et al., 2010; Sunday et al., 2012; Beaugrand, 2015; Stuart-Smith et al., 2015), and warming temperatures drive shifts in biogeographical distributions (Parmesan \& Yohe, 2003; Poloczanska et al., 2013, 2016). The simultaneous occurrence of many species outside their usual ranges has been well documented in certain regions in response to natural climate fluctuations, such as the northward shift of tropical species along the North American Pacific coastline during warm years associated with the El Niño-Southern Oscillation (Mearns, 1988). The potential rearrangement of marine ecosystems through the invasion of climate migrants beyond their poleward range margins and local extinctions of biota at equatorward range margins as global climate warms is one of the key challenges in natural resource management (Cheung et al., 2013; García Molinos et al., 2015). Meta-analyses of observations of recent range shifts of marine species showed more than $80 \%$ were shifting in directions consistent with predictions based on climate change and known species' physiological constraints (Poloczanska et al., 2013). Marine organisms have shifted their distributions by $30.6 \pm 5.2 \mathrm{~km}$ per decade, on average, with leading edges expanding by $72 \pm$ $13.5 \mathrm{~km}$ per decade (Poloczanska et al., 2013, 2016). Range shifts occur as a sequence of arrival, establishment and persistence, thus an increasing frequency of unusual sightings of species observed outside their usual ranges (here termed "first sightings") are expected as 
climate warms and the poleward ranges of marine species shift towards higher latitudes (Mearns, 1988; Arvedlund, 2009).

In response to warming temperatures, individuals and populations can acclimate and/or compensate (e.g. through thermal phenotypic plasticity, Farrell \& Franklin, 2016), shift biogeographical ranges to track temperatures, and/or undergo evolutionary adaptation (Sydeman et al., 2015). Sensitivity to warming will depend on thermal tolerances that commonly vary among complex life stages of many marine species, with early life stages generally most sensitive (Pörtner \& Farrell, 2008). Stenothermic marine species, which have narrow thermal tolerance windows and often restricted geographic ranges, may be particularly sensitive. This includes many polar species (Pörtner \& Farrell, 2008; Pörtner et al., 2014) and shallow-water tropical species that live in some of the warmest oceans, and therefore close to temperature tolerance limits (Storch et al., 2014). In contrast, temperate species with large thermal tolerance windows, large distributions, a range of genotypes (therefore increased capacity for evolutionary adaptation), and short generation times (therefore increased rate of evolutionary adaptation), are likely to be least sensitive over larger proportions of their geographical ranges (Pörtner \& Farrell, 2008). Vulnerabilities to warming, and associated range expansions and contractions are expected to be highest at the edges of current distributions, given marine species operate near their thermal limits in these regions (Pörtner \& Farrell, 2008; Sunday et al., 2012).

At the poleward (leading) edges of distributions, range expansions are anticipated with warming where organisms were previously excluded from higher latitude locations due to unfavourable climatic conditions (Bates et al., 2014). Observed shifts in species distributions reveal variability in the rate and direction of shifts within and among taxonomic groups and 
ocean regions (Pinsky et al., 2013; Poloczanska et al., 2013). This is largely due to the influence of species traits (e.g. dispersal potential), biotic interactions, habitat constraints, the presence of biogeographic barriers, and differences in regional warming rates and variability (Angert et al., 2011; Burrows et al., 2014; Sunday et al., 2015; Poloczanska et al., 2016). Consequently, it is difficult to predict when, where, and how fast individual species are likely to shift. However, modelling approaches that combine data on temperature change with information on species physiology and ecology (e.g. habitat requirements and/or dispersal ability) show how the intensity of global patterns of species' invasion and extinction may increase under warming scenarios (Cheung et al., 2009; Beaugrand et al., 2015; García Molinos et al., 2015; Jones \& Cheung, 2015). In one such approach, García Molinos et al., (2015) apply the concept of climate trajectories, derived from climate velocity (Loarie et al., 2009), which track spatial displacements of climatic niches through time, thus taking into account climate connectivity (Burrows et al., 2014). García Molinos et al., (2015) suggest that invasions are likely to dominate over local extinctions across much of the ocean outside of the tropics, leading to increases in species richness and a homogenization of marine communities.

Climate velocity trajectories outline the shortest pathways that climate migrants may follow to track their thermal niches as global climate warms, taking into account biogeographical barriers such as coastlines and oceanic fronts (Burrows et al., 2014). Climate velocity is emerging as a consistent predictor for range shifts in the ocean (Pinsky et al., 2013; Poloczanska et al., 2013). Climate velocity trajectories suggest implications of warming for changes in species distributions (Table 1), for example through the identification of areas with high risk of climate-driven immigration and emigration (Burrows et al., 2014; García Molinos et al., 2015). New arrivals of species are expected in climate convergences (areas where many 
rapid trajectories converge and slow down), corridors (areas of convergence where many rapid climate trajectories pass through), and climate sinks (areas where many rapid trajectories terminate, and therefore thermal environments are lost), as species distributions shift along trajectory paths (Burrows et al., 2014). Climate convergence regions potentially concentrate range-extending species, leading to changes in species richness and novel interactions. First sightings are predicted to be rare in climate source regions where many trajectories originate and disperse, in divergence regions (where many rapid and diverging climate trajectories pass through) and in slow- or non-moving regions (Burrows et al., 2014).

The arrival stage of a range extension constitutes the first occurrence, or first sighting, of a species at a given location. Thus, by gathering data on the likely early stages of range shifts, such as first sightings, we can develop a better appreciation of what we can expect in the future. However, not all first sightings indicate an impending climate-driven range extension, but may be the consequence of vagrancy, transport by human activities, or poor detectability (Sorte et al., 2010; Bates et al., 2014, 2015; Robinson et al., 2015). Transport by ocean currents, or species breeding or feeding migrations, are known to result in temporary seasonal occurrences of marine organisms outside their usual ranges. For example, the East Australian Current advects larval and juvenile coral reef fish southwards from tropical coral reefs into temperate waters during the Austral summer (Booth et al., 2007). These fish do not survive over winter, thus are vagrants rather than range expanders. However, global warming may result in thermal conditions that are favourable for over-winter survival by the second half of the $21^{\text {st }}$ century, and thus establishment of permanent populations (Figueira \& Booth, 2010). Species are also introduced to new regions through the unintentional or deliberate transport by human activities, such as shipping and aquaculture. However, once introduced to an area, warming can influence the potential for alien species to establish and spread (Raitsos et al., 
2010; Witte et al., 2010). These examples highlight the complexities of separating climatedriven out-of-range observations from observations due to other influences (Webber \& Scott, 2012).

Finally, a lack of reliable spatial and temporal baseline data can result in over- or underestimation of range extensions or contractions, and misclassification of range shifts (Shoo et al., 2006; Bates et al., 2014). Sampling bias can occur when the probability of detecting (Bates et al., 2015) and reporting an observation is inconsistent across the sampling region (Hefley et al., 2013). Confidence in detecting range shifts is increased through robust analytical approaches (Tingley \& Beissinger, 2009; Brown et al. 2011; Bates et al. 2015). Many intensively-sampled regions have long-term monitoring and public outreach programs, for example, the Range Extension Database and Mapping project in Australia (Redmap; www.redmap.org.au) and Sealife Survey in the UK (http://www.mba.ac.uk/recording/), thus increasing the likelihood of unusual species being reported to scientific institutions. Nevertheless, much of the ocean is poorly observed with regard to biodiversity (Ausubel et al., 2010), and the discovery rates of locally-novel species may be high in these regions (Von Der Heyden, 2011), thus increasing the potential for false climate-driven first sightings.

Detection and attribution of a range shift beyond that of natural climate variability requires identification of a climate change signal in the biological response, and statistically may not be possible for most first sightings, particularly where information on the species population dynamics and ecological requirements, as well as time series information, are lacking (Parmesan et al., 2011; 2013). Individually, confidence in an unusual observation being a first sighting is increased when multiple lines of evidence are presented within studies (Bates et al., 2014; Robinson et al., 2015), such as theoretical and mechanistic evidence presented to 
dismiss the possibility of vagrancy or introduction by human vectors. Confidence in the role of changing climate will always be lower for individual observations than for many observations combined, for example in a meta-analysis to identify a global "fingerprint" of climate change (Parmesan \& Yohe, 2003; Parmesan et al., 2013).

Here, we gather information on first sightings of marine fish, crustacea, and molluscs in coastal waters across the globe, and investigate whether these first sightings collectively are related to recent warming. We first build a database of 108 first sightings from 81 peerreviewed studies. We aggregate observations across regions to test four hypotheses: (i) that first sightings species are warm-water with regard to the latitudinal location of study, as would be expected with a climate-driven poleward shift in biodiversity, (ii) that first sightings are predominately from regions of rapid climate trajectory convergence, (iii) that first sightings are most common from climate sinks where climate trajectories are concentrated into locally-warming environments, and (iv) that first sightings are unlikely in climate sources. We use the analysis of Burrows et al., (2014; Table 1) to identify climate sinks and sources. Finally, we discuss how monitoring of first sightings of fish and other species could form part of an early-warning system for climate-driven changes in coastal biodiversity.

The early detection of climate-driven range-extending species is important for ocean management, given the potential for alteration of ecosystem structure and/or functioning, as well as economic impacts and opportunities (Mearns, 1988; Madin et al., 2012; Robinson et al., 2015). The ability to detect impending range shifts will provide us with forewarning of ecosystem changes, potentially allowing more time to develop targeted research, identify relevant conservation strategies, and adapt natural resource management to moderate or take advantage of these effects (Dawson et al., 2011). 


\section{MATERIALS AND METHODS}

\section{First Sighting Database}

We identified first sighting records from the peer-reviewed literature. First sightings were gathered through ISI Web of Science and Scopus using a list of pre-determined search terms: 'first sighting', 'first record', 'northernmost record', 'southernmost record', 'new distribution record', and 'unusual occurrence'. These searches were narrowed using 'ocean', 'marine', 'Antarctic', and 'fish'. We also searched issue-by-issue in Marine Biodiversity Records (2008-2015) and California Fish and Game (2008-2015) for reports of first sightings given these journals publish reports of unusual species observations.

To be considered for inclusion in this study, first sightings had to meet four criteria: (1) Sightings must come from peer-reviewed literature with clear taxonomic identification. First sightings of species with any apparent nomenclature issues or taxonomic confusion were excluded, as were newly described species (Robinson et al., 2015). (2) According to the authors of each study, sightings must be novel observations of species outside their known distributions, where changes in climate are a likely driver of the shift. First sightings that identify a non-climate mechanism as the most likely mode of transport (e.g. ship-mediated transport, aquaculture, or aquarium release) were excluded from this study with the exception of first sightings from studies that proposed an additional and as/more likely climate-related mechanism. We included first sightings from the Mediterranean Sea where they were not recent invasions through the Suez Canal but rather indicated the recent dispersal of established Indo-Pacific species driven by warming. Further, if the study author suggested the observation might have been associated with anomalous conditions such as extreme weather and is likely to be only a transient occurrence (e.g. due to mortality), then it was excluded. (3) 
First sightings had to be since 1991, and therefore possibly related to recent climate change.

(4) Only marine bony fishes, non-bony fishes, crustaceans, and molluscs were included.

Information extracted from each verified report included the location and year of sighting, taxonomic group and species name, and any specified evidence of a climate-related transport mechanism, such as change in temperature, upwelling, or ocean currents (Table 1). The coordinates (latitude and longitude in decimal degrees) of each report were crosschecked (using Google Maps and www.findlatitudeandlongitude.com). Where first sightings were from sampling along a transect line (e.g. from a trawl operation), the mean coordinate values of the transect were used as the sighting location.

Where a first sighting of a species occurred more than once in the same ocean region (using regionalization in Fig 30-1 of Hoegh-Guldberg et al., (2014)), we removed duplicates, leaving either the highest latitude observation, or the earliest observation where first sightings were at a similar latitude. This gave a database of 108 first sightings from 1993-2015 of 105 species from 81 peer-reviewed studies (Figure 1, Table 1). First sightings were recorded from the shelf waters of every ocean, however, $84 \%$ of observations were from northern hemisphere waters, potentially reflecting greater length of coastline and greater observational effort (Lenoir \& Svenning, 2015; Chambers et al., 2016; Figure 1).

\section{Climate datasets and sampling effort}

The first sightings dataset reveals that all observations are from shelf waters. This is not surprising given many of these observations are reported by fishers from small-scale and recreational fisheries, and long-term scientific monitoring of coastal sites. We therefore 
constrain our analysis to the region of the ocean covered by Exclusive Economic Zones (EEZ; Figure 1).

We apply the climate velocity trajectories data layer (1960-2009) of Burrows et al. (2014) using the properties of climate trajectories to classify the EEZs into areas with different inferences for climate-driven distribution shifts (Table 1). Climate trajectories were calculated in a one-degree grid (Burrows et al., 2011, 2014) using sea surface temperatures from the Hadley Centre Sea Ice and Sea Surface Temperature data set (HadISST v1.1). Climate sources and slow-moving regions are most prevalent within EEZs (24\% and 29\% of total EEZ area), while climate sink regions account for only $2 \%$ of total EEZ area (Table 1 ). We took the pattern of shifting climates over 1960-2009 to represent the long-term effects of climate on the spatial arrangement of isotherms over the periods during which first sightings were recorded, while recognising that first sighting observations are recorded during a single year or a short sequence of years. However, first sightings are likely to be the result of changes in climate and the environment that develop over much longer, but unknown, time periods. Therefore, using the longer temporal time-scale for climate is a simple, but more robust, approach than taking the climatic conditions in single years.

Data on sampling effort were supplied by the Ocean Biogeographic Information System (OBIS, 2015; http://www.iobis.org/maps). We used the count of individual sampling days with observations of biological data in each one-degree ocean grid cell, interpolated from $200,000 \mathrm{~km}^{2}$ polygons (Figure 3). Data on sampling effort were reprojected on the same onedegree grid as the climate trajectory data for the EEZ regions only. Approximately $10 \%$ of EEZs were classed with zero sampling days, and 1.3\% of EEZs have more than 1000 sampling days with biological data. 


\section{Analysis}

We tested the four hypotheses (i) that first sightings are warm-water species with regard to the latitudinal location of the study, as would be expected with a climate-driven poleward shift in biodiversity, (ii) that first sightings are predominantly from regions of rapid climate trajectory convergence, (iii) that first sightings are most common from climate sinks, where climate trajectories are concentrated into locally-warming environments, and (iv) that first sightings are unlikely in climate sources. A climate trajectory class (Figure 2) and effort value (Figure 3) was assigned for each first sighting location. Some first sightings did not overlap with the climate trajectory grid due to differences in the resolution of coastlines within the datasets. These first sightings were assigned to the nearest cell for climate trajectory type and effort.

\section{(H1) First sighting species are warm-water species with regard to latitudinal bands of}

\section{observations}

For fish species only (82.5\% of database), thermal affiliation (tropical, sub-tropical, temperate, boreal, sub-polar and polar) of each sighting species was sourced from FishBase (Froese \& Pauly, 2000). Each first sighting of a fish species was assigned to a latitude band of observation: tropical $\left(0-23.5^{\circ}\right)$, sub-tropical $\left(23.5-40^{\circ}\right)$, temperate and boreal $\left(40-66^{\circ}\right)$, and polar $\left(66-90^{\circ}\right)$. The frequency of the thermal affiliation of fish species within each latitudinal band was determined.

\section{(H2) First sightings occur most frequently in rapidly converging climate trajectory} regions

The climate trajectory dataset was split into two categories: (i) diverging/slow regions: grouping non-moving, slow-moving, sources and divergent regions (76\% of coastal cells) and (ii) converging regions: corridors, sinks and convergence regions (24\%) (Figure 2; Table 1). 
Expected proportions of first sightings were generated as the proportional frequencies of total effort in each category region. Counts of first sightings in each category were compared with expected counts as effort-derived proportions of the total number of sightings, applying Pearson's chi-squared test of independence and the effect size calculated using the Odds Ratio (OR).

\section{(H3) First sightings occur most frequently in climate sinks and (H4) First sightings are} unlikely in climate sources

We then assessed whether climate-driven range shifts are more prevalent within specific climate trajectory regions (Figure 2, Table 1) by considering the number of first sightings inside sink and source regions compared to those outside these regions. Expected counts of first sightings were derived from the distribution of sampling effort among categories as for H2. Pearson's chi-squared test of independence was applied.

\section{RESULTS}

\section{First Sighting Database}

First sightings from Atlantic Ocean EEZs dominate the database (55.5\%), with fewer first sightings from the Pacific (34\%) and Indian (7.5\%) Ocean EEZs. Only 3\% of first sightings were from the Arctic, and no observations were included for the Antarctic. First sightings of bony fish were most common $(79.5 \%)$, followed by molluscs $(11 \%)$, crustacea $(6.5 \%)$, and non-bony fish (3\%; Figure 1). Where first sightings occurred, $53 \%$ of cases had only one first sighting per grid cell observed, however one grid cell contained 10 first sightings. 
(H1) First sighting species were warm-water species with regard to latitudinal bands of observations

The majority of first-sighting fish species (bony and non-bony) in our database had tropical $(45 \%)$ or sub-tropical $(45 \%)$ thermal affiliations. Less than $4 \%$ were boreal or temperate in thermal affiliation. The majority of observations were from sub-tropical latitudes, reflecting the influence of first sightings from the well-observed waters off California in the Pacific, and in the Mediterranean Sea (Figure 1). All the first sightings in the tropical band were of tropical thermal affiliation (Figure 4). In contrast, the sub-tropical band had a mix of tropical and sub-tropical species, while the temperate and polar bands were the only bands to contain temperate and boreal species, suggesting the fish species are moving towards higher latitudes, consistent with expectations from warming.

\section{(H2) First sightings occur most frequently in rapidly converging climate trajectory} regions $46 \%$ of total first sightings were reported from converging regions (corridors, sinks and convergence areas), which accounted for $24 \%$ of total area in EEZs (Figure 2, Table 1). We found first sightings are more likely in the converging trajectory regions than in slow/diverging regions $\left(\chi^{2}(1)=29.18, \mathrm{p}<0.000 ; \mathrm{OR}=2.7295 \%\right.$ CI: 1.52, 4.86; Table 2).

\section{(H3) First sightings occur most frequently in climate sinks and (H4) First sightings are} unlikely in climate sources

First sightings reported from climate sink regions made up $14 \%$ of total first sightings (Figure

2, Table 1), which accounted for $2 \%$ of the total EEZ area. We found first sightings are more likely to occur in sink regions than not $\left(\chi^{2}(1)=86.09, p<0.000\right.$; OR $=8.55,95 \%$ CI: 1.90 , 
38.37; Table 2). 17\% of first sightings were reported from source regions (Figure 2, Table 1), which accounted for $24 \%$ of total EEZ area. We found significantly less first sightings in source regions than expected $\left(\chi^{2}(1)=3.24, \mathrm{p}<0.072\right)$. First sightings are more likely to occur in non-source regions than in source regions ( $\mathrm{OR}=1.59,95 \% \mathrm{CI}: 0.81,3.10)$.

\section{DISCUSSION}

We find that first sightings are more commonly observed in the region of rapidly converging climate trajectories (convergent, corridors and sinks) than expected based on sampling effort. In particular, first sightings are over eight times more likely in sink regions than in non-sink regions, after accounting for observational effort. The majority of our first sightings appear to be tropical and sub-tropical species moving towards high latitudes, as would be expected in a warming ocean. The high sensitivity of many coastal tropical species to climate warming (Pörtner \& Knust, 2007; Pörtner et al., 2014) coupled with relatively small range sizes, may result in a dominance of species invasions in sub-tropical regions (García Molinos et al., 2015; Jones \& Cheung, 2015). A high proportion of first sighting species in tropical and subtropical latitudes could indicate that climate warming is already having an impact on marine biodiversity at low latitudes.

First sightings in our database were clustered in four regions: the California Current, the Mediterranean, the Atlantic coast of South America, and Indian coastal waters (Figure 2). The Californian Current is a major upwelling region, which is relatively well-sampled (Figure 3).

The average sea surface temperature of the Californian Current has warmed since 1950, however the region is characterised by large inter-annual and inter-decadal climate-ecosystem variability (Hoegh-Guldberg et al., 2014), which is known to influence the appearance of novel tropical species. Unusual occurrences of tropical and sub-tropical species have occurred 
during past warm periods: for example 1926, 1931, 1941, 1958-59, 1982-83, generally coinciding, but not always, with warmer waters during El Niño events (Mearns, 1988). Mearns (1988) concludes that "unusual occurrences of marine organisms are common along this coast and collectively they indeed (but not always) form signals that may be indicative of changing ocean conditions...". Given the warming trend superimposed in climate variability in the California Current region, we anticipate increased occurrences of first sightings of tropical species in this region.

A high occurrence of first sightings in the Mediterranean Sea relates to the opening of the Suez Canal in 1869, creating an invasion pathway between the Red Sea and the Mediterranean (Lejeusne et al., 2010). However, these tropical invaders of Indo-Pacific origin were generally confined to the warm waters of the south-east Mediterranean for the first half of the twentieth century. Mediterranean warming in the second half of the twentieth century precipitated the spread of tropical species towards the northern and western regions (Lejeusne et al., 2010). For example, in the cooler northern Adriatic Sea, Mediterranean (Figure 2b), where climate velocity trajectories move through a corridor region to terminate in a climatic sink, abundances of warmer-water fish have increased in recent decades coincident with local warming (Dulčić \& Grbec, 2000; Keskin \& Pauly, 2014).

First sightings from polar regions were very rare (only 3 observations), which may reflect sampling constraints at extreme latitudes. However, the movement of temperate and sub-polar species into higher latitudes is likely to be limited by the high seasonality of light and primary production in these high latitude waters, and the adaptations required to thrive in such extreme seasonal environments (Poloczanska et al., 2016; Sundby et al., 2016). However, impacts on biodiversity are anticipated, particularly towards boreal fringes of polar regions. 
For example, large northwards shifts in sub-polar and boreal species were recorded from the north Atlantic during twentieth century warm periods and subsequent contractions with a switch to cooler temperatures (Drinkwater, 2006; Sundby et al., 2016).

As global temperatures warm, a redistribution of marine biodiversity patterns are expected (García Molinos et al., 2015; Jones \& Cheung, 2015) with consequences for ocean management and fisheries (Cheung et al., 2010). As global warming drives species invasion, establishment, and persistence in new areas (Mearns, 1988; Bates et al., 2014), the boundaries between definitions of alien species and native expanders will become blurred, potentially creating conflicts for active management (Webber \& Scott, 2012). However, opportunities may exist to include native expanders driven by climate change into monitoring and strategies to manage alien species, thus increasing capacity for early detection of impending range shifts. Approximately a third of the first sightings in our database were caught by recreational and commercial fishers and passed to marine institutions. Capacity for detection can also be expanded through targeted programs working with local communities, specifically commercial and recreational fishermen. Examples include the Alien Fish Alert program in southern Italy, which aims to gather notifications of unusual fish from local communities (Azzurro, 2010). In the UK, the Sealife Survey of the Marine Biological Association (www.mba.ac.uk/recording/) gathers observations from citizen scientists to track climatedriven and alien range changes. In Australia, the Range Extension Database and Mapping Project (Redmap; www.redmap.org.au) is a website-based citizen science initiative, where members of the public submit photographs and records of out-of-range observations, which are then verified by scientists (Pecl et al., 2014). Redmap is a growing database of first sightings, which aims to gather information on species potential range extensions as the climate changes, and to engage the public on the ecological impacts of climate change. To 
date, the eastern rock lobster (Sagmariasus verreauxi), with first sighting reports submitted to Redmap from 2012 in Tasmanian waters, is now the most logged species on Redmap (Pecl et $a l ., 2014$ ), and shows "high confidence" as a potential range extending species (Robinson et al., 2015).

Most of the observations of first sightings in our database were from the well-observed waters of the Californian Current and north-east Atlantic including the Mediterranean. However, a number of first sightings were recorded for the coastal waters of Brazil and Argentina, and for Indian coastal waters. We speculate, that this pattern may reflect publication biases to some degree, rather than observational effort. Publishing studies of first sightings in scientific literature tends to be limited to specialised journals such as Marine Biodiversity Records published for the Marine Biological Association in the UK (and discontinued in 2015), and to museum and management-related journals and magazines, such as California Fish and Game. The latter tend be less accessible to a global audience and often are published in native languages. Many of the southern American and Indian first sightings were published in Marine Biodiversity Records. There are still notable observation gaps, particularly Africa and Asia, where the implementation of citizen science programs and investigation of national museum and natural science magazines could supply valuable information on changes in biodiversity.

Using first sightings as indicators of biological responses to climate changes may be key to identifying potential range shifts before large changes in biodiversity occur. The idea that first sightings may potentially be used as indicators of impending climate-driven range shifts requires observations to be critically assessed, and combined with recent population parameters and dynamics, marine habitat assessments, and abiotic data (Arvedlund, 2009). 
Specifically, we find fast-moving climate velocity trajectory regions, particularly climate sink regions, could make ideal locations to prioritise first sighting observation programs, to provide an early warning of wider-spread ecological changes.

In summary, there is an imminent need to develop an early detection method for rangeshifting species, as range-invading species can lead to changes in species interactions, trophic pathways, and predator-prey dynamics (Doney et al., 2012; Pörtner et al., 2014), as well as affect human health and economies (Madin et al., 2012). Our results indicate that first sightings could be related to longer-term climatic processes, and could therefore be used to indicate likely climate-driven range shifts. This proposition opens up new doors for the management and detection of species range shifts, allowing the potential for prompt impact and risk assessments of range-shifting species before they colonise, and to implement proactive management strategies. The use of climate change velocity trajectories (tracing the spatial pathways of climatic niches over time (Burrows et al., 2014)) has been proposed as a broad-scale method to identify areas where rapid changes in biodiversity may occur (García Molinos et al., 2015), and our results add to the evidence for the ecological realism of this approach.

\section{ACKNOWLEDGEMENTS}

We would like to thank Ward Appletans and Mark Costello at OBIS for supplying the dataset of the global distribution of sampling effort, and Jorge García Molinos for assistance with velocity data. 


\section{REFERENCES}

Angert AL, Crozier LG, Rissler LJ, Gilman SE, Tewksbury JJ, Chunco AJ (2011) Do species' traits predict recent shifts at expanding range edges? Ecology Letters, 14, 677-689.

Arvedlund M (2009) First records of unusual marine fish distributions-can they predict climate changes? Journal of the Marine Biological Association of the United Kingdom, 89, 863-866.

Ausubel J, Trew Crist D, Waggoner P (2010) First census of marine life 2010: highlights of a decade of discovery. First CENSUS of marine life 2010: highlights of a decade of discovery.

Azzurro E (2010) Unusual occurrences of fish in the Mediterranean Sea: an insight into early detection. Fish invasions of the Mediterranean Sea: Change and Renewal, 99-126.

Bariche M, Saad M (2008) Settlement of the lessepsian blue-barred parrotfish Scarus ghobban (Teleostei: Scaridae) in the eastern Mediterranean. Marine Biodiversity Records, 1, e5.

Bates AE, Bird TJ, Stuart-Smith RD et al. (2015) Distinguishing geographical range shifts from artefacts of detectability and sampling effort. Diversity and Distributions, 21, 1322.

Bates AE, Pecl GT, Frusher S et al. (2014) Defining and observing stages of climatemediated range shifts in marine systems. Global Environmental Change, 26, 27-38.

Beaugrand G (2015) Theoretical basis for predicting climate-induced abrupt shifts in the oceans. Philosophical Transactions of the Royal Society B-Biological Sciences, 370, 20130264.

Beaugrand G, Edwards M, Raybaud V, Goberville E, Kirby RR (2015) Future vulnerability of marine biodiversity compared with contemporary and past changes. Nature Climate Change, 5, 695-701. 
Bianchi CN (2007) Biodiversity issues for the forthcoming tropical Mediterranean Sea. Hydrobiologia, 580, 7-21

Booth DJ, Figueira WF, Gregson MA, Brown L, Beretta G (2007) Occurrence of tropical fishes in temperate southeastern Australia: Role of the East Australian Current. Estuarine Coastal and Shelf Science, 72, 102-114.

Brown CJ, Schoeman DS, Sydeman WJ, et al. (2011) Quantitative approaches in climate change ecology. Global Change Biology, 17, 3697-3713.

Burrows MT, Schoeman DS, Buckley LB et al. (2011) The pace of shifting climate in marine and terrestrial ecosystems. Science, 334, 652-655.

Burrows MT, Schoeman DS, Richardson AJ et al. (2014) Geographical limits to speciesrange shifts are suggested by climate velocity. Nature, 507, 492-495.

Chambers LE, Barnard P, Poloczanska ES, Hobday AJ, Keatley MR, Allsopp N, Underhill LG (2016) Southern hemisphere biodiversity and global change: data gaps and strategies. Austral Ecology, in press.

Cheung WWL, Lam VWY, Sarmiento JL, Kearney K, Watson R, Pauly D (2009) Projecting global marine biodiversity impacts under climate change scenarios. Fish and Fisheries, 10, 235-251.

Cheung WWL, Lam VWY, Sarmiento JL, Kearney K, Watson REG, Zeller D, Pauly D (2010) Large-scale redistribution of maximum fisheries catch potential in the global ocean under climate change. Global Change Biology, 16, 24-35.

Cheung WWL, Watson R, Pauly D (2013) Signature of ocean warming in global fisheries catch. Nature, 497, 365-369.

Dawson TP, Jackson ST, House JI, Prentice IC, Mace GM (2011) Beyond predictions: Biodiversity conservation in a changing climate. Science, 332, 53-58. 
Doney SC, Ruckelshaus M, Duffy JE et al. (2012) Climate change impacts on marine ecosystems. Annual Review of Marine Science, 4, 11-37.

Drinkwater KF (2006) The regime shift of the 1920s and 1930s in the North Atlantic. Progress in Oceanography, 68, 134.

Dulčić J, Grbec B (2000) Climate change and Adriatic ichthyofauna. Fisheries Oceanography, 9, 187-191.

Edelist D, Rilov G, Golani D, Carlton JT, Spanier E (2013) Restructuring the sea: profound shifts in the world's most invaded marine ecosystem. Diversity and Distributions, 19, 69-77.

Farrell AP, Franklin CE (2016) Recognizing thermal plasticity in fish. Science, 351, 132-133. Figueira WF, Booth DJ (2010) Increasing ocean temperatures allow tropical fishes to survive overwinter in temperate waters. Global Change Biology, 16, 506-516.

Fortibuoni T, Aldighieri F, Giovanardi O, Pranovi F, Zucchetta M (2015) Climate impact on Italian fisheries (Mediterranean Sea). Regional Environmental Change, 15, 931-937.

Froese R, Pauly D (2000) Fishbase 2000: concepts, design and data sources, Los Baños, Laguna, Philippines, ICLARM.

García Molinos J, Halpern BS, Schoeman DS et al. (2015) Climate velocity and the future global redistribution of marine biodiversity. Nature Climate Change, 6, 83-88.

Hefley TJ, Tyre AJ, Baasch DM, Blankenship EE (2013) Nondetection sampling bias in marked presence-only data. Ecology and Evolution, 3, 5225-5236.

Hoegh-Guldberg O, Cai R, Poloczanska ES et al. (2014) The Ocean. In: Climate Change 2014: Impacts, Adaptation, and Vulnerability. Part B: Regional Aspects. Contribution of Working Group II to the Fifth Assessment Report of the Intergovernmental Panel on Climate Change. (eds Barros VR, Field CB, Dokken DJ, Mastrandrea MD, Mach KJ, Bilir TE, Chatterjee M, Ebi KL, Estrada YO, Genova RC, Girma B, Kissel ES, Levy 
AN, Maccracken S, Mastrandrea PR, White LL) pp 688. Cambridge, United Kingdom and New York, NY, USA, Cambridge University Press.

Jones MC, Cheung WWL (2015) Multi-model ensemble projections of climate change effects on global marine biodiversity. ICES Journal of Marine Science: Journal du Conseil, 72, 741-752.

Keskin C, Pauly D (2014) Changes in the 'Mean Temperature of the Catch': application of a new concept to the North-eastern Aegean Sea. Acta Adriatica, 55, 213-218.

Lejeusne C, Chevaldonne P, Pergent-Martini C, Boudouresque CF, Perez T (2010) Climate change effects on a miniature ocean: the highly diverse, highly impacted Mediterranean Sea. Trends in Ecology \& Evolution, 25, 250-260.

Lenoir J, Svenning JC (2015) Climate-related range shifts-a global multidimensional synthesis and new research directions. Ecography, 38, 15-28.

Loarie SR, Duffy PB, Hamilton H, Asner GP, Field CB, Ackerly DD (2009) The velocity of climate change. Nature, 462, 1052-1055.

Madin EMP, Ban NC, Doubleday ZA, Holmes TH, Pecl GT, Smith F (2012) Socio-economic and management implications of range-shifting species in marine systems. Global Environmental Change, 22, 137-146.

Mearns AJ (1988) The "odd fish": unusual occurrences of marine life as indicators of changing ocean conditions. In: Marine organisms as indicators. pp 137-176, Springer New York.

OBIS (2015) Global biodiversity indices from the Ocean Biogeographic Information System. Intergovernmental Oceanographic Commission of UNESCO. Web. http://www.iobis.org (consulted on 2015/08/11). 
Parmesan C, Burrows MT, Duarte CM, Poloczanska ES, Richardson AJ, Schoeman DS, Singer MC (2013) Beyond climate change attribution in conservation and ecological research. Ecology Letters, 16, 58-71.

Parmesan C, Duarte C, Poloczanska E, Richardson AJ, Singer MC (2011) COMMENTARY: Overstretching attribution. Nature Climate Change, 1, 2-4.

Parmesan C, Yohe G (2003) A globally coherent fingerprint of climate change impacts across natural systems. Nature, 421, 37-42.

Pecl G, Barry Y, Brown R et al. (2014) Redmap: ecological monitoring and community engagement through citizen science. The Tasmanian Naturalist, 136, 158-164.

Pinsky ML, Worm B, Fogarty MJ, Sarmiento JL, Levin SA (2013) Marine taxa track local climate velocities. Science, 341, 1239-1242.

Poloczanska ES, Brown CJ, Sydeman WJ et al. (2013) Global imprint of climate change on marine life. Nature Climate Change, 3, 919-925.

Poloczanska ES, Burrows MT, Brown CJ et al. (2016) Responses of marine organisms to climate change across oceans. Frontiers in Marine Science, 3, 62.

Pörtner H-O, Farrell AP (2008) Physiology and climate change. Science, 322, 690-692. Pörtner H-O, Karl DM, Boyd PW, Cheung WWL, Lluch-Cota SE, Nojiri Y, Schmidt DN (2014) Ocean Systems. In: Climate Change 2014: Impacts, Adaptation, and Vulnerability. Part A: Global and Sectoral Aspects. Contribution of Working Group II to the Fifth Assessment Report of the Intergovernmental Panel on Climate Change. (eds Field CB, Barros VR, Dokken DJ, Mach KJ, Mastrandrea MD, Bilir TE, Chatterjee M, Ebi KL, Estrada YO, Genova RC, Girma B, Kissel ES, Levy AN, Maccracken S, Mastrandrea PR, White LL) pp 411-484. Cambridge, United Kingdom and New York, NY, USA, Cambridge University Press. 
Pörtner H-O, Knust R (2007) Climate change affects marine fishes through the oxygen limitation of thermal tolerance. Science, 315, 95-97.

Raitsos DE, Beaugrand G, Georgopoulos D, Zenetos A, Pancucci-Papadopoulou AM, Theocharis A, Papathanassiou E (2010) Global climate change amplifies the entry of tropical species into the Eastern Mediterranean Sea. Limnology and Oceanography, 55, 1478-1484.

Robinson LM, Gledhill DC, Moltschaniwskyj NA et al. (2015) Rapid assessment of an ocean warming hotspot reveals "high" confidence in potential species' range extensions. Global Environmental Change, 31, 28-37.

Shoo LP, Williams SE, Hero J-M (2006) Detecting climate change induced range shifts: where and how should we be looking? Austral Ecology, 31, 22-29.

Sorte CJB, Williams SL, Carlton JT (2010) Marine range shifts and species introductions: comparative spread rates and community impacts. Global Ecology and Biogeography, 19, 303-316.

Storch D, Menzel L, Frickenhaus S, Pörtner H-O (2014) Climate sensitivity across marine domains of life: limits to evolutionary adaptation shape species interactions. Global Change Biology, 20, 3059-3067.

Stuart-Smith RD, Edgar GJ, Barrett NS, Kininmonth SJ, Bates AE (2015) Thermal biases and vulnerability to warming in the world's marine fauna. Nature, 528, 88-92.

Sunday JM, Bates AE, Dulvy NK (2012) Thermal tolerance and the global redistribution of animals. Nature Climate Change, 2, 686-690.

Sunday JM, Pecl GT, Frusher S et al. (2015) Species traits and climate velocity explain geographic range shifts in an ocean-warming hotspot. Ecology Letters, 18, 944-953.

Sundby S, Drinkwater KF, Kjesbu OS (2016) The North Atlantic spring-bloom systemwhere the changing climate meets the winter dark. Frontiers in Marine Science, 3, 28. 
Sydeman WJ, Poloczanska E, Reed TE, Thompson SA (2015) Climate change and marine vertebrates. Science, 350, 772-777.

Tingley MW, Beissinger SR (2009) Detecting range shifts from historical species occurrences: new perspectives on old data. Trends in Ecology \& Evolution, 24, 625633.

Tittensor DP, Mora C, Jetz, W, Lotze, HK, Ricard, D, Berghe, EV, Worm, B (2010) Global patterns and predictors of marine biodiversity across taxa. Nature, 466, 1098-1101.

Von Der Heyden S (2011) 'Carry on sampling!'- assessing marine fish biodiversity and discovery rates in southern Africa. Diversity and Distributions, 17, 81-92.

Webber BL, Scott JK (2012) Rapid global change: implications for defining natives and aliens. Global Ecology and Biogeography, 21, 305-311.

Witte S, Buschbaum C, Van Beusekom JEE, Reise K (2010) Does climatic warming explain why an introduced barnacle finally takes over after a lag of more than 50 years? Biological Invasions, 12, 3579-3589.

\section{FIGURE CAPTIONS}

Figure 1. Global distribution of 108 'first sightings' (observations outside of species' usual ranges) of 105 marine species over the period 1993-2015 in Exclusive Economic Zones (grey shading) from 81 peer-reviewed studies where recent climate change is inferred to be a driver of the occurrence of each species outside their usual range. Red = bony fish, orange = nonbony fish, yellow $=$ molluscs, green $=$ crustaceans .

Figure 2. Distribution of climate velocity trajectory classes, from Burrows et al. (2014), and first sightings in Exclusive Economic Zones A) globally, B) Europe, C) South America, D) India, and E) west coast USA. Corridor, convergence and sink cells (pink, orange and red) 
are fast-moving regions where isotherms are converging. Black stars indicate the location of 'first sightings' (Figure 1). Full description of trajectory classes and implications of species shifts are given in Table 1 and Burrows et al. (2014).

Figure 3. Sampling effort in Exclusive Economic Zones from Ocean Biogeographic Information System (OBIS, 2015; www.iobis.org). Data are the number of individual sampling days with observations of biological data. Black stars indicate the location of 'first sightings' (Figure 1).

Figure 4. Frequency of first sighting fish species by thermal affiliation in latitudinal bands ( $\chi^{2}$ $(2)=18.86, \mathrm{p}<0.0001)$. Thermal affiliation was taken from FishBase. Latitudinal bands were combined for both hemispheres and defined as $0-23.5^{\circ}=$ tropical, $23.5-40^{\circ}=$ subtropical, $40-66^{\circ}=$ temperate $($ and boreal $), 66-90^{\circ}=$ polar . 
Table 1. Climate velocity trajectory classes (slow-, non- and fast-moving, with fast-moving sub-classes) based on trajectory behaviour and \% area of Exclusive Economic Zones covered by each. Implications for species range shifts and species richness, if species are tracking thermal environments, are given. From Burrows et al. (2014).

\begin{tabular}{|c|c|c|c|c|c|}
\hline $\begin{array}{l}\text { Trajectory } \\
\text { Class }\end{array}$ & $\begin{array}{l}\% \\
\text { EEZ }\end{array}$ & Characteristics & $\begin{array}{l}\text { Climate } \\
\text { connectivity }\end{array}$ & $\begin{array}{l}\text { Effects on } \\
\text { distributions }\end{array}$ & $\begin{array}{l}\text { Effects on } \\
\text { species } \\
\text { richness }\end{array}$ \\
\hline Non-Moving & $7 \%$ & Short trajectories. & Little thermal shift. & $\begin{array}{l}\text { Climate migration } \\
\text { is not expected. }\end{array}$ & Stable. \\
\hline Slow-Moving & $29 \%$ & $\begin{array}{l}\text { Moderate length } \\
\text { trajectories. }\end{array}$ & $\begin{array}{l}\text { Slow-moderate } \\
\text { thermal shift. }\end{array}$ & $\begin{array}{l}\text { Little climate } \\
\text { migration. }\end{array}$ & Stable. \\
\hline Fast-Moving & $64 \%$ & Long trajectories. & Thermal shifts. & $\begin{array}{l}\text { Climate migrants } \\
\text { expected. }\end{array}$ & Unstable. \\
\hline $\begin{array}{l}\text { Source } \\
\text { (diverging) }\end{array}$ & $24 \%$ & $\begin{array}{l}\text { Areas where } \\
\text { many trajectories } \\
\text { start and move } \\
\text { out. }\end{array}$ & $\begin{array}{l}\text { Regions where } \\
\text { thermal } \\
\text { environments are } \\
\text { generated. These are } \\
\text { locally novel } \\
\text { climate conditions, } \\
\text { disconnected } \\
\text { warmer locales. }\end{array}$ & $\begin{array}{l}\text { High emigration } \\
\text { as climate } \\
\text { migrants shift } \\
\text { away from these } \\
\text { regions as they } \\
\text { track the } \\
\text { movement of their } \\
\text { preferred thermal } \\
\text { niche (leading } \\
\text { edge expansions). } \\
\text { No immigrations. }\end{array}$ & $\begin{array}{l}\text { Species } \\
\text { richness } \\
\text { declines as } \\
\text { climate } \\
\text { emigrants are } \\
\text { not replaced. } \\
\text { Empty niches } \\
\text { increase risk of } \\
\text { invasive } \\
\text { species. }\end{array}$ \\
\hline Convergence & $13 \%$ & $\begin{array}{l}\text { Areas of flow- } \\
\text { through where } \\
\text { fewer trajectories } \\
\text { end than start. }\end{array}$ & $\begin{array}{l}\text { Regions of large } \\
\text { trajectory } \\
\text { movement, where } \\
\text { trajectories } \\
\text { originating from }\end{array}$ & $\begin{array}{l}\text { Moderate } \\
\text { potential for } \\
\text { climate migration. }\end{array}$ & $\begin{array}{l}\text { Richness } \\
\text { change depends } \\
\text { on balance of } \\
\text { climate } \\
\text { emigrants and }\end{array}$ \\
\hline
\end{tabular}

This article is protected by copyright. All rights reserved. 


\begin{tabular}{|c|c|c|c|c|c|}
\hline & & & $\begin{array}{l}\text { many areas gather } \\
\text { and slow. }\end{array}$ & & immigrants. \\
\hline $\begin{array}{l}\text { Corridor } \\
\text { (converging) }\end{array}$ & $9 \%$ & $\begin{array}{l}\text { Many trajectories } \\
\text { originating over a } \\
\text { wide area, } \\
\text { concentrate. A } \\
\text { high proportion of } \\
\text { trajectories } \\
\text { passing through. }\end{array}$ & $\begin{array}{l}\text { A 'climatic } \\
\text { freeway', where } \\
\text { trajectories } \\
\text { converge and move } \\
\text { rapidly in the same } \\
\text { direction. }\end{array}$ & $\begin{array}{l}\text { High climate } \\
\text { emigration and } \\
\text { immigration. } \\
\text { Many climate } \\
\text { migrants from } \\
\text { geographically } \\
\text { distinct locations. }\end{array}$ & $\begin{array}{l}\text { Richness stable } \\
\text { or increased. } \\
\text { Increased effect } \\
\text { of species } \\
\text { interactions on } \\
\text { richness. }\end{array}$ \\
\hline Divergence & $16 \%$ & $\begin{array}{l}\text { Areas of flow- } \\
\text { through where } \\
\text { more trajectories } \\
\text { end than start. }\end{array}$ & $\begin{array}{l}\text { Regions of large } \\
\text { trajectory } \\
\text { movement, where } \\
\text { trajectories disperse } \\
\text { and speed up. }\end{array}$ & $\begin{array}{l}\text { Moderate } \\
\text { potential for } \\
\text { climate migration. }\end{array}$ & $\begin{array}{l}\text { Richness } \\
\text { change depends } \\
\text { on balance of } \\
\text { climate } \\
\text { emigrants and } \\
\text { immigrants. }\end{array}$ \\
\hline $\begin{array}{l}\text { Sink } \\
\text { (converging) }\end{array}$ & $2 \%$ & $\begin{array}{l}\text { Areas where } \\
\text { many trajectories } \\
\text { enter and end. }\end{array}$ & $\begin{array}{l}\text { Regions } \\
\text { disconnected from } \\
\text { cooler locales. } \\
\text { Local thermal } \\
\text { environments are } \\
\text { lost. }\end{array}$ & $\begin{array}{l}\text { High climate } \\
\text { immigration as } \\
\text { climate migrants } \\
\text { shift into these } \\
\text { regions (leading } \\
\text { edge expansions) } \\
\text { and any further } \\
\text { shift is inhibited. } \\
\text { High risk of local } \\
\text { extinctions (for } \\
\text { trailing edges). }\end{array}$ & $\begin{array}{l}\text { Richness stable } \\
\text { or increased. } \\
\text { Local } \\
\text { extinction } \\
\text { possible but } \\
\text { species } \\
\text { replaced. }\end{array}$ \\
\hline
\end{tabular}




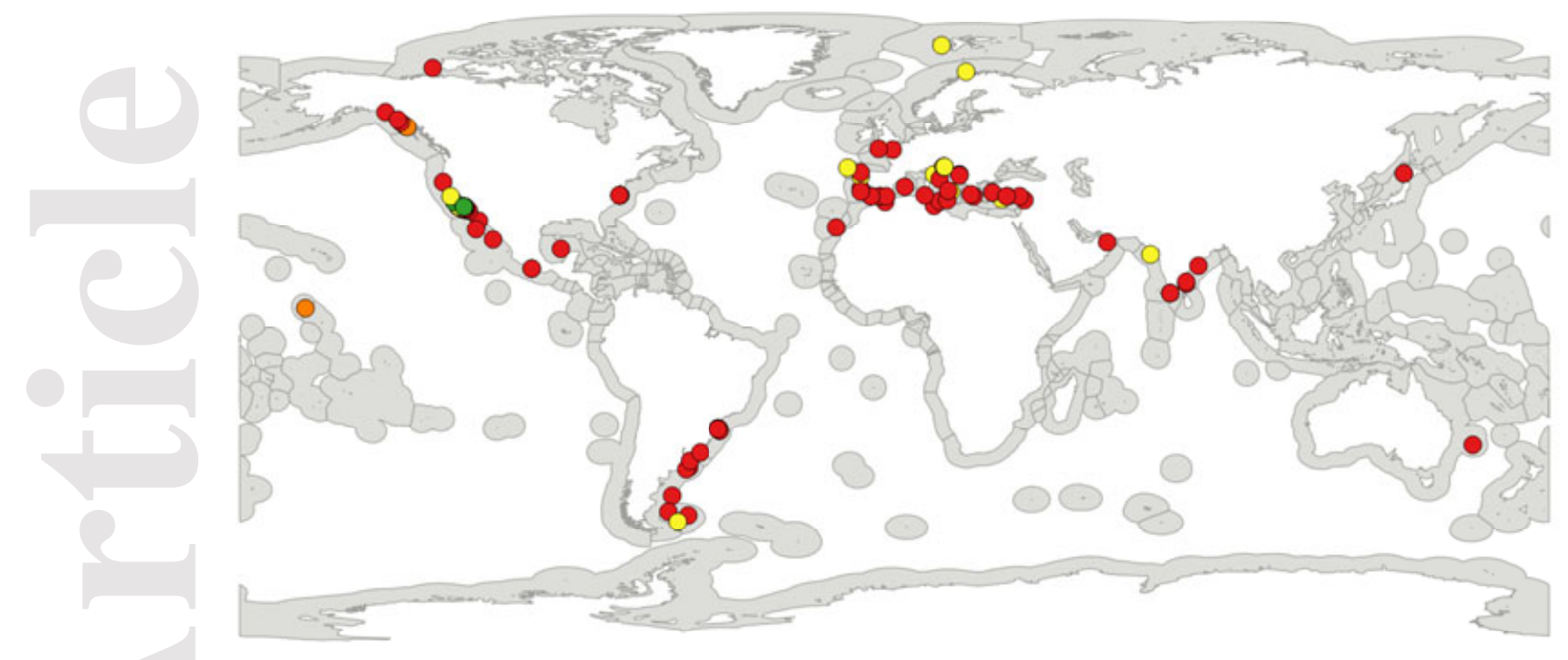

This article is protected by copyright. All rights reserved. 
(a)
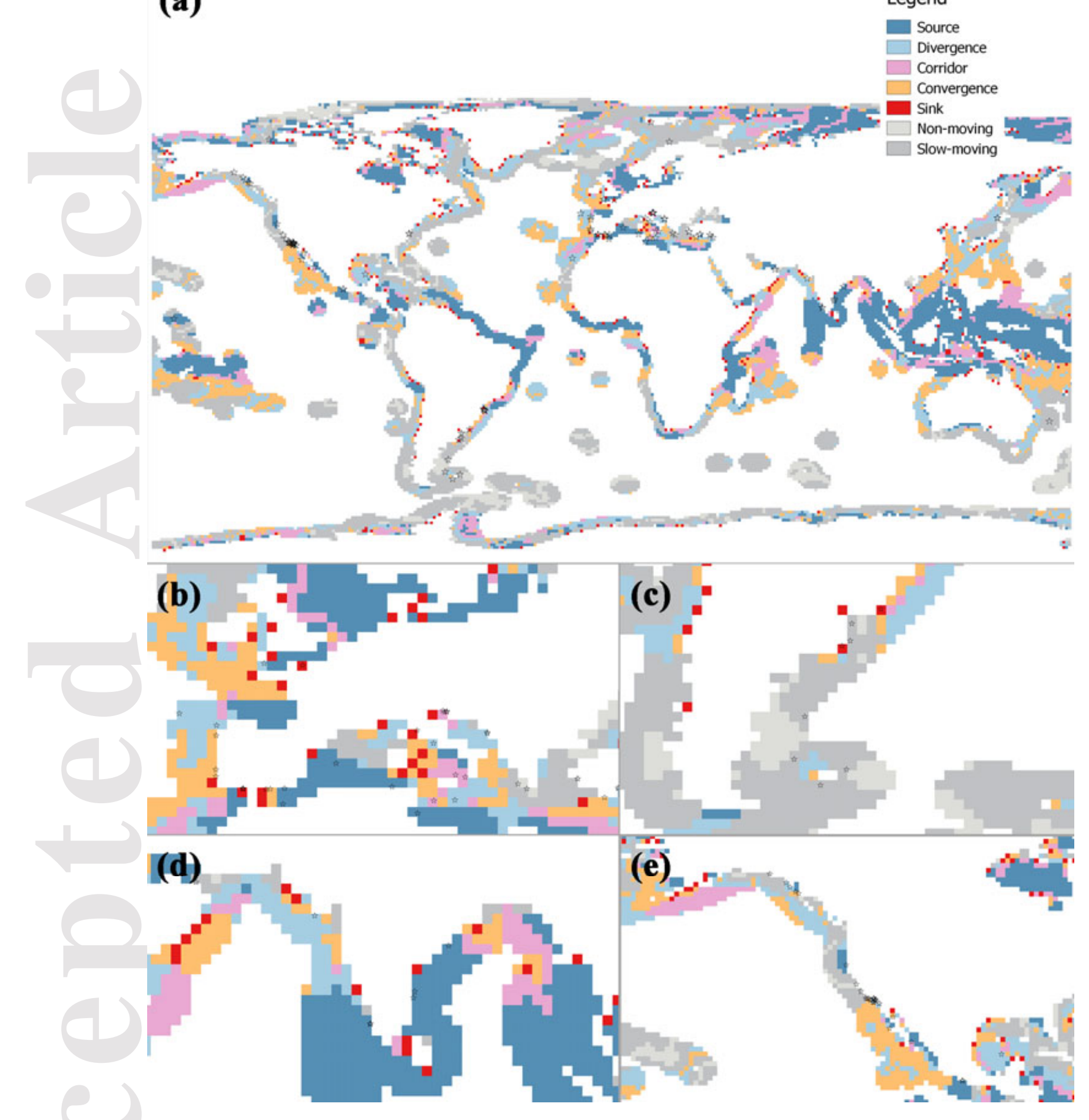

This article is protected by copyright. All rights reserved. 

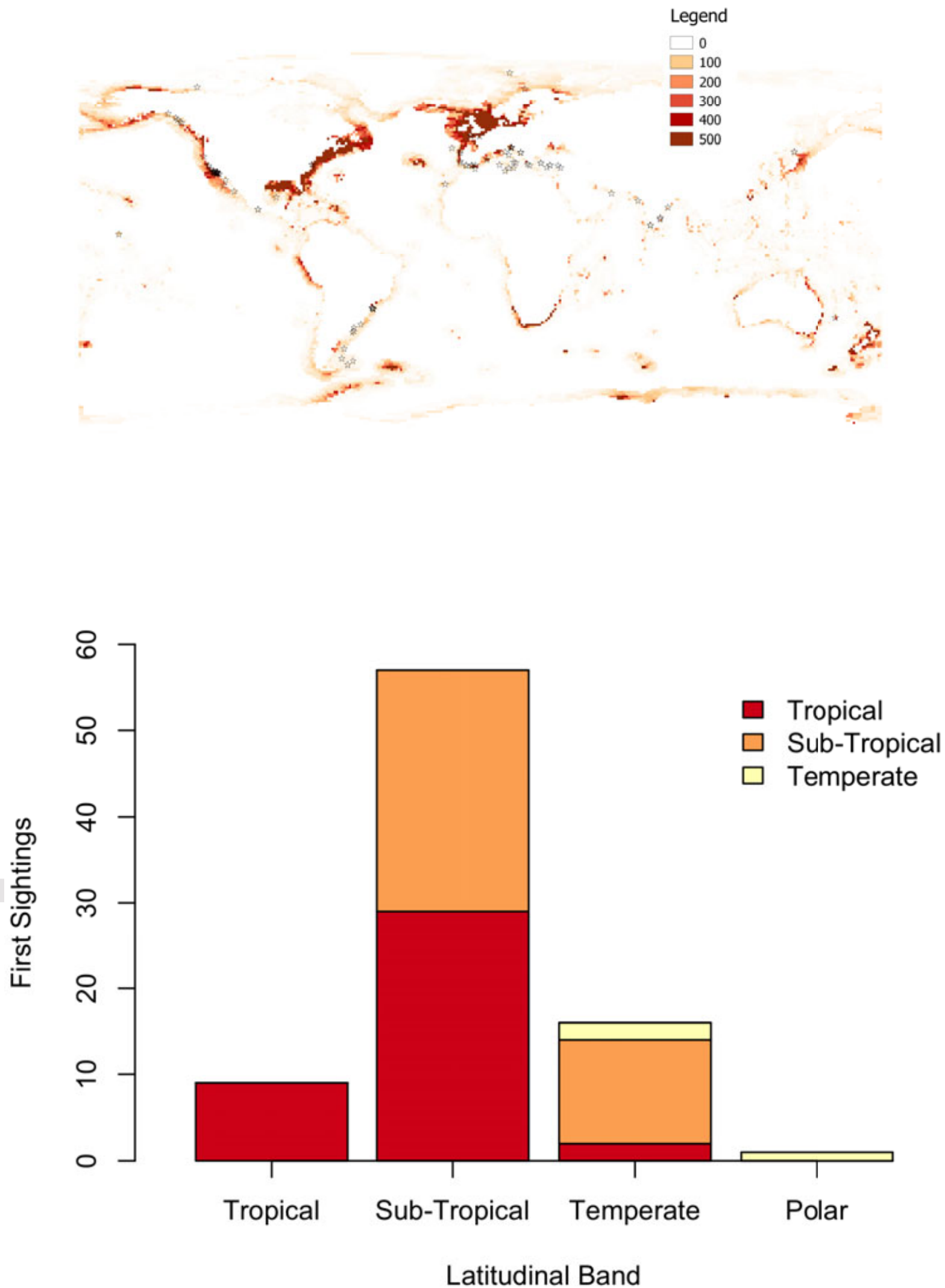

This article is protected by copyright. All rights reserved. 